\title{
High-throughput mRNA sequencing of stromal cells from endometriomas and endometrium
}

\author{
Kadri Rekker ${ }^{1,2}$, Merli Saare ${ }^{1,2}$, Elo Eriste², Tõnis Tasa ${ }^{3,4}$, Viktorija Kukuškina ${ }^{4,5}$, Anne Mari Roost ${ }^{2}$, \\ Kristi Anderson ${ }^{2}$, Külli Samuel ${ }^{2}$, Helle Karro ${ }^{1,6}$, Andres Salumets ${ }^{1,2,7,8}$ and Maire Peters ${ }^{1,2}$ \\ ${ }^{1}$ Department of Obstetrics and Gynecology, Institute of Clinical Medicine, University of Tartu, Tartu, Estonia, \\ ${ }^{2}$ Competence Centre on Health Technologies, Tartu, Estonia, ${ }^{3}$ Institute of Computer Science, University of Tartu, \\ Tartu, Estonia, ${ }^{4}$ Estonian Genome Center, University of Tartu, Tartu, Estonia, ${ }^{5}$ Institute of Molecular and Cell Biology, \\ University of Tartu, Tartu, Estonia, ${ }^{6}$ Tartu University Hospital's Women's Clinic, Tartu, Estonia, 'Department of \\ Biomedicine, Institute of Biomedicine and Translational Medicine, University of Tartu, Tartu, Estonia and \\ ${ }^{8}$ Department of Obstetrics and Gynecology, University of Helsinki and Helsinki University Hospital, \\ Helsinki, Finland \\ Correspondence should be addressed to K Rekker; Email: kadri.rekker@gmail.com
}

\begin{abstract}
The aetiology of endometriosis is still unclear and to find mechanisms behind the disease development, it is important to study each cell type from endometrium and ectopic lesions independently. The objective of this study was to uncover complete mRNA profiles in uncultured stromal cells from paired samples of endometriomas and eutopic endometrium. High-throughput mRNA sequencing revealed over 1300 dysregulated genes in stromal cells from ectopic lesions, including several novel genes in the context of endometriosis. Functional annotation analysis of differentially expressed genes highlighted pathways related to cell adhesion, extracellular matrix-receptor interaction and complement and coagulation cascade. Most importantly, we found a simultaneous upregulation of complement system components and inhibitors, indicating major imbalances in complement regulation in ectopic stromal cells. We also performed in vitro experiments to evaluate the effect of endometriosis patients' peritoneal fluid (PF) on complement system gene expression levels, but no significant impact of PF on C3, CD55 and CFH levels was observed. In conclusion, the use of isolated stromal cells enables to determine gene expression levels without the background interference of other cell types. In the future, a new standard design studying all cell types from endometriotic lesions separately should be applied to reveal novel mechanisms behind endometriosis pathogenesis.
\end{abstract}

Reproduction (2017) 154 93-100

\section{Introduction}

Endometrial tissue outside the uterine cavity can form lesions on ovaries and other peritoneal organs, resulting in endometriosis. As the molecular aetiology of endometriosis is still unclear, it is important to detect gene expression alterations in endometriotic lesions and eutopic endometrium of endometriosis patients. Three major types of endometriotic lesions are known, peritoneal lesions, ovarian endometriomas and deep infiltrating lesions (Nisolle \& Donnez 1997), that are distinct clinical entities with unique histopathogeneses accompanied by specific expression profiles, depending on the anatomical location of lesions (Meola et al. 2010, Ballester et al. 2012, Filippi et al. 2016). Therefore, it seems reasonable to study endometriomas and lesions from other locations separately.

Several transcriptomic studies have been conducted to find molecular alterations in endometrial cells lining the inner surface of endometriomas (reviewed in Sanchez et al. 2015). However, despite hundreds to thousands of genes and specific pathways that have been revealed in these studies, the results remain inconclusive and no common molecular markers or pathways linked to endometriosis have been described. The most probable reason for these discordances could be the tissue heterogeneity of whole-lesion biopsies, as in addition to endometrial cells the endometrioma wall includes various proportions of ovarian stroma, follicles and fibrous tissue that prevent the detection of gene expression alterations characteristic to ectopic endometrial cells (reviewed in Sanchez et al. 2014). There are only a few studies utilizing pure cell populations for exploring gene expression in endometriotic lesions. The first study applied laser capture microdissection to gather epithelial cells from eu- and ectopic endometrial tissues (Wu et al. 2006), while another study analysed cultured immortalized stromal cells from ovarian endometriosis 
(Kobayashi et al. 2012). The studies investigating gene expression alterations in purified and uncultured stromal cells from eu- and ectopic endometrial tissues are still missing, but could be a helpful source of information to understand the disease pathogenesis.

Therefore, the aim of the current study was to reveal the full transcriptome of uncultured endometrial stromal cells from paired samples of endometriomas and endometrium of the same woman.

\section{Materials and methods}

\section{Patient characteristics and sample collection}

The study protocol was approved by Research Ethics Committee of the University of Tartu (Tartu, Estonia). Patients were enrolled in the study from Tartu University Hospital's Women's Clinic after signing a written informed consent form. Endometriomas and eutopic endometrial tissue samples were obtained from 10 women to isolate stromal cells by fluorescence-activated cell sorting (FACS, Table 1). From nine patients (six with and three without endometriosis), eutopic endometrial samples were collected to establish primary cell cultures (Table 1). All tissue samples were collected during laparoscopy for suspected endometriosis or infertility.

Table 1 General characteristics of the study participants.

\begin{tabular}{|c|c|c|c|c|c|}
\hline Patient ID & $\begin{array}{c}\text { Age } \\
\text { (years) }\end{array}$ & $\begin{array}{c}\text { BMI } \\
\left(\mathrm{kg} / \mathrm{m}^{2}\right)\end{array}$ & $\begin{array}{l}\text { Menstrual } \\
\text { cycle } \\
\text { phase }^{c}\end{array}$ & $\begin{array}{l}\text { Endo- } \\
\text { metriosis } \\
\text { stage }\end{array}$ & Infertility \\
\hline \multicolumn{6}{|c|}{$\mathrm{CD} 10^{+}$stromal cell study } \\
\hline $\mathrm{E} 213^{\mathrm{a}, \mathrm{b}}$ & 43 & 24.0 & Proliferative & III & No \\
\hline $\mathrm{E} 218^{\mathrm{a}, \mathrm{b}}$ & 32 & 28.6 & Proliferative & III & Yes, primary \\
\hline $\mathrm{E} 238^{\mathrm{a}, \mathrm{b}}$ & 32 & 20.0 & Proliferative & IV & Yes, secondary \\
\hline $\mathrm{E} 244^{\mathrm{a}, \mathrm{b}}$ & 28 & 17.8 & Proliferative & III & Yes, secondary \\
\hline $\mathrm{E} 160^{\mathrm{b}}$ & 31 & 19.7 & Proliferative & IV & No \\
\hline $\mathrm{E} 230^{\mathrm{b}}$ & 35 & 17.6 & Proliferative & IV & No \\
\hline $\mathrm{E} 270^{\mathrm{b}}$ & 33 & 21.5 & Proliferative & III & Yes, secondary \\
\hline $\mathrm{E} 302^{\mathrm{b}}$ & 40 & 25.4 & Proliferative & III & Yes, primary \\
\hline E097b & 25 & 17.9 & Proliferative & III & Yes, primary \\
\hline $\mathrm{E} 224^{\mathrm{b}}$ & 30 & 21.1 & Proliferative & II & No \\
\hline \multicolumn{6}{|c|}{ Cell culture study } \\
\hline E305* & 30 & 29.1 & Proliferative & NA & Yes, primary \\
\hline E339* & 32 & 21.8 & Proliferative & NA & Yes, secondary \\
\hline E324* & 26 & 21.0 & Proliferative & NA & Yes, primary \\
\hline E279 & 22 & 21.4 & Proliferative & I & Yes, primary \\
\hline E316 & 28 & 19.0 & Proliferative & 1 & No \\
\hline E306 & 25 & 19.1 & Proliferative & I & Yes, secondary \\
\hline E142 & 31 & 20.1 & Proliferative & IV & Yes, primary \\
\hline $\mathrm{E} 302$ & 40 & 25.4 & Proliferative & III & Yes, primary \\
\hline E343 & 26 & 20.5 & Proliferative & I & Yes, primary \\
\hline \multicolumn{6}{|c|}{ Peritoneal fluid pool } \\
\hline E314 & 44 & 22.2 & Secretory & III & No \\
\hline E316 & 28 & 19.0 & Proliferative & I & No \\
\hline E327 & 35 & 20.2 & Proliferative & IV & No \\
\hline E330 & 35 & 24.5 & Secretory & III & Yes, secondary \\
\hline E331 & 30 & 23.4 & Proliferative & II & No \\
\hline E319 & 30 & 19.6 & Secretory & III & Yes, primary \\
\hline
\end{tabular}

${ }^{a}$ mRNA sequencing, ${ }^{b}$ validation, cbased on the date of last menstruation reported by patient and *patients without endometriosis.
Endometrial samples were obtained using an endometrial suction catheter (Pipelle, Laboratoire CCD, Paris, France). Recruited women had not received hormonal medications at least three months before surgery. All collected tissue samples were immediately placed into the cryopreservation medium containing $1 \times$ Dulbecco's Modified Eagle's Medium (DMEM, Gibco, Thermo Fisher Scientific), 30\% fetal bovine serum (FBS, Biowest, Riverside, MO, USA) and 7.5\% Dimethyl Sulfoxide Hybri-Max (Sigma-Aldrich), placed into Nalgene Cryo $1^{\circ} \mathrm{C} ' \mathrm{Mr}$ Frosty' Freezing Container (Thermo Scientific) and deposited into a $-80^{\circ} \mathrm{C}$ freezer overnight. The frozen biopsies were stored in liquid nitrogen until further use. A proportion of the freshly collected endometrioma samples was placed into formalin for histopathological evaluation, and endometriosis diagnosis was verified on all endometrioma samples.

From a subset of patients (Table 1), peritoneal fluid (PF) was aspirated into a sterile $15 \mathrm{~mL}$ polystyrene tube and transported to the laboratory on ice within one hour. Blood-contaminated PFs were not collected. The PF was centrifuged $(15 \mathrm{~min}$, $1200 \mathrm{~g}$, at $4^{\circ} \mathrm{C}$ ), filtered through a $0.22 \mu \mathrm{m}$ pore size membrane (Millex GV filter, Merck Millipore) and stored at $-80^{\circ} \mathrm{C}$ until further use.

\section{Stromal cell isolation from eu- and ectopic endometria}

Stromal cells were isolated from endometrial or endometrioma biopsies using FACS as described previously (Krjutskov et al. 2016) with minor modifications for ectopic endometria. Briefly, endometrioma samples were rapidly thawed $(<1 \mathrm{~min})$ in a $37^{\circ} \mathrm{C}$ water bath, rinsed with medium, minced with sterile scalpel and then enzymatically digested with collagenase (Sigma-Aldrich) for up to $1 \mathrm{~h}$. Erythrocytes were removed with ACK lysing buffer (Gibco, Thermo Fisher Scientific), and cell suspensions were filtered through $50 \mu \mathrm{m}$ and $35 \mu \mathrm{m}$ strainer (Cell Strainer Cap, BD Falcon, San Jose, CA, USA) to separate cells from undigested tissue fragments. Isolated cells from eu- and ectopic endometria were stained with phycoerythrinconjugated mouse anti-human CD10 antibody (1:20 dilution, clone HI10a, BD Pharmingen, USA) and prior to FACS, DAPI $(1 \mathrm{mg} / \mathrm{mL}, 1: 2000$ dilution, Invitrogen) was added to the suspension to exclude dead cells from the analysis. On average, the viability of cells was $76.4 \%$ (ranging from 71.8 to $81.2 \%$ ) and $76.4 \%$ (ranging from 72.4 to $83.2 \%$ ) for endometrial and endometrioma biopsies, respectively. Alive CD10+ cells were sorted directly to QIAzol Lysis Reagent (Qiagen). Total RNA was isolated immediately using RNeasy Micro kit (Qiagen).

\section{RNA sequencing}

Before library construction, RNA was treated with DNA-free DNA Removal Kit (Invitrogen, Thermo Fisher Scientific), and the quality of the total RNA was analysed on Bioanalyzer 2100 using RNA 6000 Nano chips (Agilent Technologies). Library construction and sequencing were performed at the Estonian Genome Center Core Facility (Tartu, Estonia). 100 bp pairedend mRNA libraries were prepared using TruSeq Stranded mRNA Library Prep Kit (Illumina, San Diego, CA, USA) as per manufacturer's instructions and were sequenced on Illumina HiSeq2500. 


\section{Sequencing data analysis}

Raw sequencing reads were quality controlled using FastQC version 0.9 .5 (http://www.bioinformatics.bbsrc.ac.uk/projects/ fastqc/) and cutadapt version 1.8.1 (Martin 2011). Qualitycontrolled reads were aligned to the human genome (NCBI build 37, hg19) using STAR (version 2.4.0j) alignment tool (Dobin et al. 2013). Gene and transcript level quantification of read counts was performed using HTSeq version 0.6.1 (Anders et al. 2015). Differentially expressed genes (DEGs) between stromal cells from eutopic and ectopic endometria were identified using the edgeR (Robinson et al. 2010), DESeq2 (Love et al. 2014) and baySeq (v2) (Hardcastle 2016) packages. DEGs were defined as follows: (a) with adjusted $P$ value $\leq 0.05$, (b) with at least 2 -fold difference between compared samples and (c) recognized by at least two out of three differential expression detection methods used. Biological mechanisms underlying DEGs were investigated using g:Profiler (Reimand et al. 2016).

\section{Experiments with peritoneal fluid (PF)}

Six PF samples collected from endometriosis patients (Table 1) were thawed, pooled together in equal amounts and the same PF pool was used in all experiments. Preconditioning experiments to optimize the supplemental PF concentration for endometrial cell cultures were performed with increasing amounts of PF pool $(0,10$ or $25 \%$ of final concentration). As also previously demonstrated (Braza-Boils et al. 2015), 25\% of final PF concentration was not toxic to cells (data not shown), and was used for further experiments.

Primary cultures of human endometrial stromal cells were prepared from frozen endometrial biopsies collected from nine patients (four with I-II stage endometriosis, two with III-IV stage endometriosis and three without endometriosis, Table 1). Single-cell suspensions of endometrial stromal cells for primary culture were isolated as described previously (Kasvandik et al. 2016), isolated cells were seeded into the 24-well cell culture plate and cultured at $37^{\circ} \mathrm{C}$ in $5 \% \mathrm{CO}_{2}$ until $90 \%$ of confluency was reached. Then medium was removed, and cells were washed twice with $\mathrm{Mg}^{2+}$ - and $\mathrm{Ca}^{2+}$-free PBS. After washing, cells were treated either with medium containing PF $(25 \%$ of final concentration) or without PF ( $0 \%$ of final concentration), supplemented with $100 \mathrm{pM}$ oestradiol (Sigma-Aldrich) and incubated for 6,12 and 24 at $37^{\circ} \mathrm{C}, 5 \% \mathrm{CO}_{2}$ (Fig. 1A). After the exposure time, cells were washed twice with $\mathrm{Mg}^{2+}$ - and $\mathrm{Ca}^{2+}$-free PBS, detached using $0.25 \%$ trypsin/0.02\% EDTA (Gibco, Thermo Fisher Scientific) at $37^{\circ} \mathrm{C}, 15 \mathrm{~min}$. For trypsin inactivation, the full media of DMEM/F12 with $10 \%$ FBS serum was added to the cell suspension and collected to low-binding tubes (Eppendorf, Hamburg, Germany). Cells were pelleted at $300 \mathrm{~g}$ for $5 \mathrm{~min}$ at room temperature and lysed with QIAzol Lysis Reagent for subsequent RNA extraction. Total RNA was isolated using RNeasy Micro kit (Qiagen).

\section{Real-time PCR}

The relative expression of complement cascade genes $(C 3$, CD55, CFH, A2M and SERPINA5), cell adhesion-related genes (SELP, ESAM, CLDN1 and CLDN11) and SERPINE2 was verified in uncultured stromal cells isolated by FACS from nine eutopic and 10 ectopic endometrial tissues (Table 1). Complement cascade genes $\mathrm{C} 3, \mathrm{CD} 55$ and $\mathrm{CFH}$ were also quantified from primary cultures of endometrial stromal cells conditioned with or without PF. cDNA was synthesized with RevertAid First Strand cDNA Synthesis Kit (Thermo Fisher Scientific), and real-time PCR was performed using $1 \times$ HOT FIREPol EvaGreen qPCR Mix Plus (ROX) (Solis BioDyne, Tartu, Estonia).
A

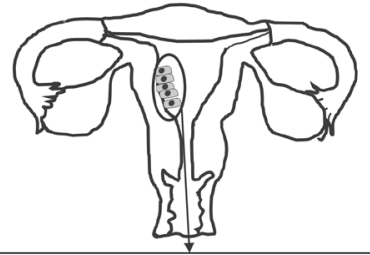

Endometrium from women with $(n=6)$ and without $(n=3)$ endometriosis

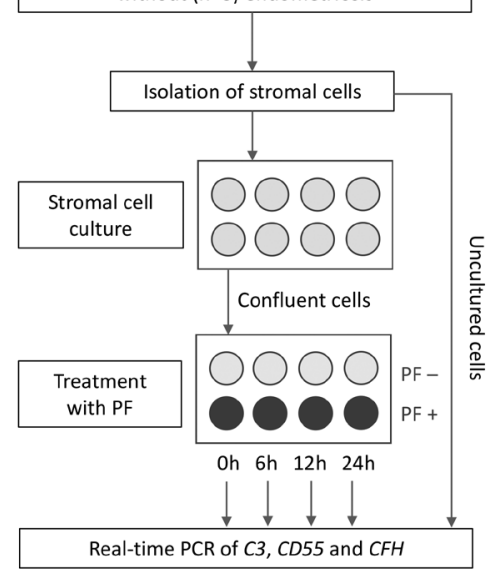

Real-time PCR of $C 3, C D 55$ and $C F H$
B

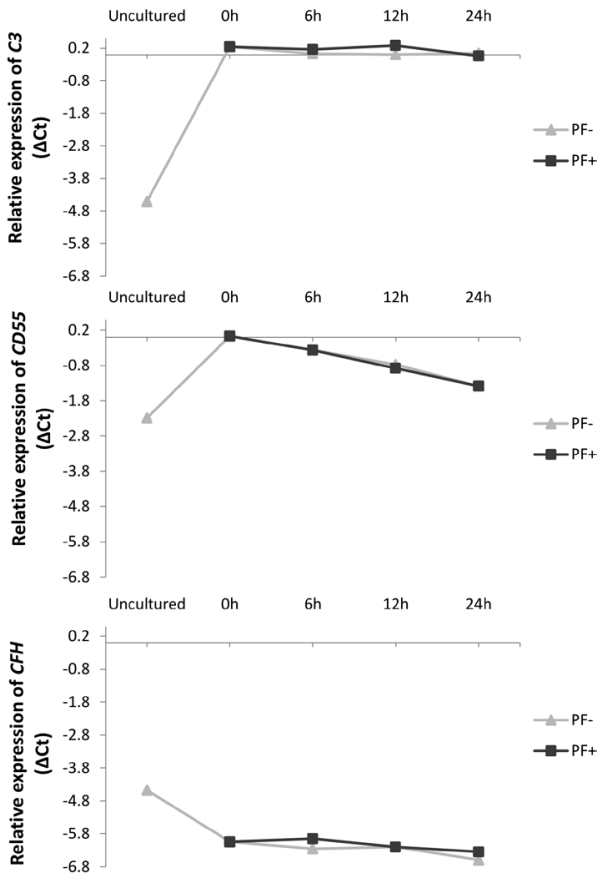

Figure 1 (A) Experimental design of PF study; (B) average relative expression of complement cascade genes in PF experiments. The relative expression of $C 3, C D 55$ and $C F H$ was measured from cells before cultivation (uncultured), after achieving confluency but before treatment with $\mathrm{PF}(0 \mathrm{~h})$, and 6, 12 and $24 \mathrm{~h}$ after adding PF. In parallel, untreated cells from the same biopsies were cultured and analysed at the same time points; PF, peritoneal fluid. 
Table 2 Primer sequences used in the study.

\begin{tabular}{|c|c|c|}
\hline Gene name & Strand & Primer sequence $5^{\prime} \rightarrow 3^{\prime}$ \\
\hline \multirow[t]{2}{*}{ ESAM } & Forward & CСTTTCGTCTTCCATGGCTG \\
\hline & Reverse & AGCAACCCCAGTCCAACC \\
\hline \multirow[t]{2}{*}{$A 2 M$} & Forward & AGTCTGGTTCTTCTССTCTTGG \\
\hline & Reverse & СССТGACAGАСТССАAGGAA \\
\hline \multirow[t]{2}{*}{ SERPINA5 } & Forward & GAACCTCGATAGCAATGCGG \\
\hline & Reverse & AGTGATACTGATCCTCGCGG \\
\hline \multirow[t]{2}{*}{ SELP } & Forward & GTCAGCTACTCCACCAACCT \\
\hline & Reverse & АСТGСТGTССАТTGTССТGA \\
\hline \multirow[t]{2}{*}{ CLDN1 } & Forward & GTGCGATATTTCTTCTTGCAGGTC \\
\hline & Reverse & TTCGTACCTGGCATTGACTGG \\
\hline \multirow[t]{2}{*}{ CLDN11 } & Forward & GTACСАСТGCAAGССССТ \\
\hline & Reverse & TCAGCAGCAGTAAAATGGCC \\
\hline \multirow[t]{2}{*}{ SERPINE2 } & Forward & AATGAAACCAGGGATATGATTGAC \\
\hline & Reverse & TTGCAAGATATGAGAAACATGGAG \\
\hline \multirow[t]{2}{*}{$\mathrm{C} 3$} & Forward & GACTCCATCACCACGTGGGA \\
\hline & Reverse & ССTGCATTACTGTGACCTCGAA \\
\hline \multirow[t]{2}{*}{ CD55 } & Forward & TCCTGGCGAGAAGGACTCAGTGA \\
\hline & Reverse & AGCCTTGTTGGCACCTCGCA \\
\hline \multirow[t]{2}{*}{$\mathrm{CFH}$} & Forward & TTGCACACAAGATGGATGGT \\
\hline & Reverse & GGATGCATCTGGGAGTAGGA \\
\hline \multirow[t]{2}{*}{$S D H A$} & Forward & TGGGAACAAGAGGGCATCTG \\
\hline & Reverse & ССАССАСТGСАТСАААТTСАТG \\
\hline
\end{tabular}

SDHA was used as a reference gene. Primer sequences are listed in Table 2. Fold change (FC) was calculated according to the $2^{-\Delta \Delta \mathrm{Ct}}$ method (Livak \& Schmittgen 2001). Studied mRNA differences between eu- and ectopic endometrial stromal cells were analysed with two-tailed Student's $t$-test, and $P$ value $\leq 0.05$ was considered as significant. Relative expression levels in studied PF experiment groups at different time points were compared using ANOVA and Tukey-Kramer post hoc test.

\section{Results}

\section{Gene expression profile of eu- and ectopic endometrial stromal cells}

To identify DEGs between eutopic endometria and ovarian endometriomas, mRNA sequencing was performed on stromal cells isolated from four paired tissue samples. On average, 7.6 million reads (between 7.0 and 8.6 million per sample) were obtained using Illumina HiSeq2500 platform of which 93\% had highquality scores $(\geq Q 30)$. Data analysis revealed 1395 DEGs (FC $\geq 2$, adjusted $P$ values $<0.05$ ) from which 339 and 1056 genes were more abundantly expressed in eutopic and ectopic endometrium, respectively (Supplementary Table 1, see section on supplementary data given at the end of this article). The top 15 most significantly down- and up-regulated genes are listed in Table 3.

Functional annotation analysis of all DEGs utilizing g:Profiler software revealed 'Cell adhesion molecules' (26 genes, $P$ value 8.2E-08), 'ECM-receptor interaction' (17 genes, $P$ value $3.0 \mathrm{E}-05)$ and 'Complement and coagulation cascades' (16 genes, $P$ value $5.6 \mathrm{E}-04$ ) as the most enriched KEGG pathways (Supplementary Table 2).
Among other cell adhesion molecules, CLDN1, -5 and -11 , cadherins and several major histocompatibility complex genes were present. 'Complement and coagulation cascade' pathway included highly upregulated genes in endometriomas, such as C3, C7 and SERPINA5 (Table 3), and several integrin genes (ITGA4, ITGA7, ITGA10, ITGA11 and ITGB4) from 'ECM-receptor interaction' pathway were differentially expressed in studied cells (Supplementary Table 2). In addition, various other pathways were highlighted by g:Profiler software where 'Calcium signalling pathway' and 'PI3K-Akt signalling pathway' had the highest number of DEGs involved (29 and 43 genes, respectively; Supplementary Table 2).

\section{Validation of selected DEGs}

Several genes from the complement cascade, cell adhesion pathways and SERPINE2 were selected according to sequencing data for further validation in stromal cells from eu- and ectopic endometrial tissues. Real-time PCR analyses confirmed differential expression of all studied genes (Fig. 2), showing upregulation in ectopic endometrial stroma.

\section{Complement pathway genes in endometrial stromal cells are not regulated by PF from endometriosis patients}

Next, in order to find out whether the higher expression of complement pathway genes in lesions could be caused by PF composition of endometriosis patients, primary eutopic endometrial stromal cells from nine women (three women without endometriosis and six women with the disease) were cultured and treated with cell culture medium containing $25 \%$ of PF collected from endometriosis patients. To avoid bias from individual differences in PF composition, pooled PF from six endometriosis patients with different stages of the disease was used. The relative expression of C3, CD55 and CFH was measured from cells before cultivation (uncultured), after achieving confluency but before treatment with PF $(0 \mathrm{~h})$, and 6,12 and $24 \mathrm{~h}$ after adding PF. In parallel, untreated cells from the same biopsies were cultured and analysed at the same time points (Fig. 1A).

The uncultured stromal cells showed gene expression levels comparable to FACS-isolated stromal cells used for determining the mRNA differences between euand ectopic samples. The studied expression levels in endometrial stromal cells of endometriosis-free women and patients with the disease were similar and were grouped together for further analysis. No significant impact of PF on C3, CD55 and CFH levels in stromal cells were observed during the 24-h treatment time compared to untreated cells (Fig. 1B; all $P>0.05$ ); 
Table 3 Top 15 up- and downregulated genes between stromal cells from endometriomas and endometrium.

\begin{tabular}{|c|c|c|c|}
\hline Gene & Description & Log2 fold change & Adjusted $\boldsymbol{P}$ value (BaySeq) \\
\hline \multicolumn{4}{|c|}{ Upregulated in endometriomas } \\
\hline $\mathrm{C} 3$ & Complement component 3 & 7.9 & $6.4 \mathrm{E}-11$ \\
\hline$H P$ & Haptoglobin & 8.7 & 1.7E-05 \\
\hline SERPINA5 & Serpin family A member 5 & 6.7 & 3.6E-05 \\
\hline FMO2 & Flavin-containing monooxygenase 2 & 6.4 & 5.7E-05 \\
\hline TCF23 & Transcription factor 23 & 5.9 & $7.8 \mathrm{E}-05$ \\
\hline S100A10 & S100 calcium-binding protein $\mathrm{A} 10$ & 6.2 & $1.3 \mathrm{E}-04$ \\
\hline$C 7$ & Complement component 7 & 7.6 & $1.6 \mathrm{E}-04$ \\
\hline NR5A1 & Nuclear receptor subfamily 5 group A member 1 & 8.8 & $2.2 \mathrm{E}-04$ \\
\hline BST2 & Bone marrow stromal cell antigen 2 & 5.0 & $3.5 \mathrm{E}-04$ \\
\hline GPX3 & Glutathione peroxidase 3 & 6.4 & $3.9 \mathrm{E}-04$ \\
\hline DAPK1 & Death-associated protein kinase 1 & 4.4 & 4.4E-04 \\
\hline SLC19A3 & Solute carrier family 19 member 3 & 6.5 & $4.8 \mathrm{E}-04$ \\
\hline CLDN11 & Claudin 11 & 6.5 & $6.3 \mathrm{E}-04$ \\
\hline ARHGEF28 & Rho guanine nucleotide exchange factor 28 & 3.9 & $6.9 \mathrm{E}-04$ \\
\hline SCN7A & Sodium voltage-gated channel alpha subunit 7 & 8.5 & 8.7E-04 \\
\hline \multicolumn{4}{|c|}{ Downregulated in endometriomas } \\
\hline KIAA1210 & KIAA1210 & -5.2 & 5.7E-06 \\
\hline C8orf31 & Chromosome 8 open reading frame 31 & -4.5 & $1.0 \mathrm{E}-04$ \\
\hline SDK2 & Sidekick cell adhesion molecule 2 & -4.4 & $1.9 \mathrm{E}-04$ \\
\hline DOK7 & Docking protein 7 & -5.4 & $2.6 \mathrm{E}-04$ \\
\hline LRFN5 & Leucine-rich repeat and fibronectin type III domain containing 5 & -4.1 & $3.0 \mathrm{E}-04$ \\
\hline TMEM120B & Transmembrane protein $120 \mathrm{~B}$ & -2.6 & $5.3 \mathrm{E}-04$ \\
\hline GUCY1A2 & Guanylate cyclase 1 , soluble, alpha 2 & -2.7 & 7.5E-04 \\
\hline$P P P 2 R 2 C$ & Protein phosphatase 2 regulatory subunit Bgamma & -5.8 & 8.1E-04 \\
\hline ADAMTS16 & ADAM metallopeptidase with thrombospondin type 1 motif 16 & -4.5 & $1.0 \mathrm{E}-03$ \\
\hline RCOR2 & REST corepressor 2 & -3.2 & $1.2 \mathrm{E}-03$ \\
\hline TMEM132B & Transmembrane protein $132 \mathrm{~B}$ & -4.2 & $1.4 \mathrm{E}-03$ \\
\hline HSD11B2 & Hydroxysteroid 11-beta dehydrogenase 2 & -5.1 & $1.8 \mathrm{E}-03$ \\
\hline ARSJ & Arylsulfatase family member J & -3.2 & 2.0E-03 \\
\hline GDF7 & Growth differentiation factor 7 & -5.2 & $2.2 \mathrm{E}-03$ \\
\hline DUSP15 & Dual specificity phosphatase 15 & -2.2 & $2.3 \mathrm{E}-03$ \\
\hline
\end{tabular}

however, considerable increase in $C 3$ and $C D 55$, and decrease in $C F H$ levels were detected in cultured $(0,6$, 12 and $24 \mathrm{~h}$ ) vs uncultured cells (Fig. $1 \mathrm{~B}$; all $P<0.05$ ), indicating that cell culturing per se had larger effect on complement gene expression levels compared to the influence of PF.

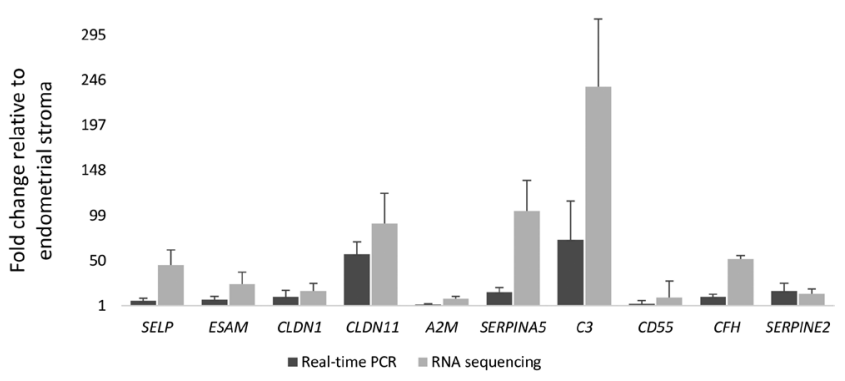

Figure 2 Gene expression level differences between stromal cells from endometrium and endometriomas studied by RNA sequencing and quantitative real-time PCR. Fold change values are given relative to endometrial stroma. All studied gene expression differences were statistically significant $(P<0.05)$. The error bars denote S.E.M. (standard error of the mean).

\section{Discussion}

Endometriotic lesion biopsies typically contain only a small proportion of endometrial stromal and epithelial cells in addition to various other cell types and surrounding tissue that impedes the detection of gene expression alterations in endometriotic cells (Sanchez et al. 2015). In addition, molecular profiles correlate to the anatomical location of lesions (Meola et al. 2010, Ballester et al. 2012, Filippi et al. 2016) and therefore specific cell populations from the selected type of lesions should be studied. For the first time to our knowledge, we used high-throughput mRNA sequencing to reveal transcriptome changes in uncultured endometrial stromal cells from endometriomas and paired samples of eutopic endometrium. Our analysis revealed over 1300 DEGs, and confirmed associations between endometriosis and numerous pathways, including cell adhesion along with complement and coagulation cascade.

It is widely accepted that the impairment of innate immune system via the complement system plays a crucial part in the pathogenesis of endometriosis. Higher expression of complement components, e.g. C3, C7, CFH and CFD, in endometriomas has been 
demonstrated (Kobayashi et al. 2012, Suryawanshi et al. 2014, Ahn et al. 2016) and, in our study, C3 showed the most significantly altered levels between eu- and ectopic endometrial stromal cells (Table 3). Moreover, in our study, complement central components $(C 3, C 7$, $C 1 Q A$ and $C 1 Q B)$ as well as complement inhibitors (CD55, CFH, C4BPB, SERPING1 and CLU) were upregulated at the same time. Complement regulatory proteins (including $\mathrm{CD} 55, \mathrm{CFH}$ and $\mathrm{C} 4 \mathrm{BP}$ ) prevent the complement system from being activated when it is not needed (Ferreira et al. 2010, Toomey et al. 2014). Several tumour cells express complement regulatory proteins at very high levels to protect the tissue from complementdependent cytotoxicity (Morgan et al. 2002). For example, in endometrial tumours, the overexpression of complement regulatory proteins CD55 and protectin has been linked to high resistance to complement-mediated cell destruction (Bellone et al. 2012). Therefore, we can speculate that the imbalances in complement activation and inhibition in endometriotic cells result in inflammation and, on the other hand, protect the cells at extrauterine location.

It has been hypothesised that one of the factors affecting complement gene expression levels in endometrial cells outside the normal environment is PF (Tao et al. 1997). PF is in direct contact with all pelvic surfaces where endometriotic lesions are most often located and seems to play a pivotal role in the pathogenesis of endometriosis by influencing the anatomical distribution of lesions (Bricou et al. 2008). In addition, PF of endometriosis patients has an altered composition (Gilabert-Estelles et al. 2007, Berkes et al. 2014, Liu et al. 2016) that can modify miRNA expression of endometrial stromal cells (Braza-Boils et al. 2015). Moreover, the PF of endometriosis patients contains increased levels of cytokines (Taketani et al. 1992, Khorram et al. 1993, Pizzo et al. 2002) that can cause gene expression changes in endometrial stromal cells, including complement cascade genes (Chalpe 2015). Although an upregulation of several complement components in endometriomas has been previously demonstrated (Eyster et al. 2007, Hever et al. 2007, Borghese et al. 2008, Suryawanshi et al. 2014, Ahn et al. 2016), we were the first who examined the influence of endometriosis PF on the expression level of complement components in endometrial stromal cells. Nevertheless, no differences in C3, CD55 and CFH levels were detected in cultured endometrial stromal cells treated with PF from endometriosis patients compared to untreated cultured stromal cells from the same patients. Thus, some factors other than the altered composition of PF must be involved in the complement gene regulation in endometriosis. However, differences in complement cascade gene expression levels were observed between cultured and uncultured stromal cells indicating that cell culturing has a significant impact on gene expression, an issue previously demonstrated by Barragan et al. (2016).
We also observed a rise in cell adhesion molecule (CAM) pathway gene levels in ectopic endometrial stromal cells. Increased levels of CAMs, including claudins, selectins, integrins and cadherins have been linked to the development and persistence of endometriotic lesions in peritoneal environment (Witz 2003). CAMs take part in intercellular adhesion and interaction with the extracellular matrix. Through this mechanism, CAMs facilitate the binding of endometrial cells to ectopic sites. Besides cell-to-cell interactions, CAMs mediate various immune and inflammatory processes (Malik \& Lo 1996), an attribute very commonly described in endometriosis. Aside from previously described CAMs, our sequencing data revealed several novel cell adhesion pathway genes including ESAM, CD6, CDH3, MAG, LRRC4B, NFASC, NLGN1 and $N R X N 1$ that have not been described in relation to endometriosis before (Supplementary Table 1). Thereby, our study results confirmed the relevance of CAMs in the pathogenesis of endometriosis and added several novel candidates to the list of endometriosis-associated CAM-genes.

Several pathways highlighted in our study have also been linked to tumorigenesis (focal adhesion, ECM-receptor interaction, cytokine-cytokine receptor interaction and PI3K-Akt signalling pathway). Endometriosis and ovarian cancer share numerous common features including high oestrogen and cytokine concentration, oxidative stress, etc. that may activate these pathways; however, the association between endometriosis and ovarian cancer is still unclear, and it is generally accepted that endometriosis does not increase cancer incidence (Dunselman et al. 2014).

On protein level, our previous study revealed that the protein with the highest difference (FC 19.2) between cultured ectopic and eutopic stromal cells was glia-derived nexin (encoded by SERPINE2 gene) (Kasvandik et al. 2016). In the current study, we also demonstrated an overexpression of SERPINE2 mRNA (FC 17.1) in uncultured ectopic stromal cells. In cancers, the main functions of SERPINE2 are enhancement of cellular invasiveness and extracellular matrix production (Buchholz et al. 2003). Therefore, our results collectively hint that SERPINE2 could play a pivotal role in the pathogenesis of endometriosis by altering stromal cell invasive capabilities.

Despite the small number of samples in our mRNA sequencing analysis, we detected substantial differences in gene expression levels between eu- and ectopic endometrial stroma. The number of false positive associations was diminished using three differential expression analysis packages, and DEGs were considered true if confirmed by at least two analysis methods. The verification of selected targets by realtime PCR confirmed the results of mRNA sequencing. The validity of our results is further supported by several previous studies reporting similar findings 
(Eyster et al. 2007, Hever et al. 2007, Borghese et al. 2008, Sohler et al. 2013, Suryawanshi et al. 2014, Ahn et al. 2016), suggesting that if a certain gene is highly upregulated in endometrial cells from ectopic location, the surrounding tissue does not hinder the detection of this gene. In addition, as we analysed the specific population of stromal cells from endometrioma and endometrium, we were able to identify several new genes previously not described in endometriosis studies. Therefore, studying specific cell populations has clear advantages over analysing whole tissue biopsies, as this approach enables to reveal changes that occur in certain endometrial cells. For example, an increased expression of genes associated with leukocytes (e.g. CD4, CD45R0, CD8A,CD3D and CD48) has been observed in endometriotic lesions (Ahn et al. 2016). In our study, we did not detect higher expression of these genes in stromal cells from lesions compared to eutopic endometrium, demonstrating that exploring specific cell populations enables to study changes that have occurred particularly in endometrial cells from ectopic locations.

In conclusion, this is the first study utilizing uncultured $\mathrm{CD} 0^{+}$stromal cells to discover large-scale alterations from eu- and ectopic endometria of endometriosis patients. Our data confirmed the upregulation of several cell adhesion molecules and complement components in endometriotic stromal cells and added new molecular candidates for further studies in pathogenesis of endometriosis. The benefits of the current study in identifying novel genes in endometriosis provide proof that in the future, all cell types of endometriotic lesions should be examined separately to uncover mechanisms for the disease development that have thus far remained hidden.

\section{Supplementary data}

This is linked to the online version of the paper at http://dx.doi. org/10.1530/REP-17-0092.

\section{Declaration of interest}

The authors declare that there is no conflict of interest that could be perceived as prejudicing the impartiality of the research reported.

\section{Funding}

This research was funded by grant IUT34-16 from the Estonian Ministry of Education and Research; Enterprise Estonia, grant no EU48695; FP7 Marie Curie Industry-Academia Partnerships and Pathways (IAPP) grant (SARM, EU324509) and Horizon 2020 innovation programme (WIDENLIFE, 692065).

\section{Acknowledgements}

The authors are very grateful to the staff of Tartu University Hospital's Women's Clinic for collecting the samples and to the women who participated in this study. We also acknowledge Triin Laisk-Podar for the critical reading of the manuscript.

\section{References}

Ahn SH, Khalaj K, Young SL, Lessey BA, Koti M \& Tayade C 2016 Immuneinflammation gene signatures in endometriosis patients. Fertility and Sterility 106 1420-1431. (doi:10.1016/j.fertnstert.2016.07.005)

Anders S, Pyl PT \& Huber W 2015 HTSeq - a Python framework to work with high-throughput sequencing data. Bioinformatics 31 166-169. (doi:10.1093/bioinformatics/btu638)

Ballester M, Gonin J, Rodenas A, Bernaudin JF, Rouzier R, Coutant C \& Darai E 2012 Eutopic endometrium and peritoneal, ovarian and colorectal endometriotic tissues express a different profile of nectin-1, $-3,-4$ and nectin-like molecule 2. Human Reproduction 27 3179-3186. (doi:10.1093/humrep/des304)

Barragan F, Irwin JC, Balayan S, Erikson DW, Chen JC, Houshdaran S, Piltonen TT, Spitzer TL, George A, Rabban JT et al. 2016 Human endometrial fibroblasts derived from mesenchymal progenitors inherit progesterone resistance and acquire an inflammatory phenotype in the endometrial niche in endometriosis. Biology of Reproduction 94118. (doi:10.1095/biolreprod.115.136010)

Bellone S, Roque D, Cocco E, Gasparrini S, Bortolomai I, Buza N, AbuKhalaf M, Silasi DA, Ratner E, Azodi M et al. 2012 Downregulation of membrane complement inhibitors CD55 and CD59 by siRNA sensitises uterine serous carcinoma overexpressing Her2/neu to complement and antibody-dependent cell cytotoxicity in vitro: implications for trastuzumab-based immunotherapy. British Journal of Cancer 106 1543-1550. (doi:10.1038/bjc.2012.132)

Berkes E, Oehmke F, Tinneberg HR, Preissner KT \& Saffarzadeh M 2014 Association of neutrophil extracellular traps with endometriosisrelated chronic inflammation. European Journal of Obstetrics and Gynecology and Reproductive Biology 183 193-200. (doi:10.1016/j. ejogrb.2014.10.040)

Borghese B, Mondon F, Noel JC, Fayt I, Mignot TM, Vaiman D \& Chapron C 2008 Gene expression profile for ectopic versus eutopic endometrium provides new insights into endometriosis oncogenic potential. Molecular Endocrinology 22 2557-2562. (doi:10.1210/me.2008-0322)

Braza-Boils A, Salloum-Asfar S, Mari-Alexandre J, Arroyo AB, GonzalezConejero R, Barcelo-Molina M, Garcia-Oms J, Vicente V, Estelles A, Gilabert-Estelles J et al. 2015 Peritoneal fluid modifies the microRNA expression profile in endometrial and endometriotic cells from women with endometriosis. Human Reproduction 30 2292-2302. (doi:10.1093/ humrep/dev204)

Bricou A, Batt RE \& Chapron C 2008 Peritoneal fluid flow influences anatomical distribution of endometriotic lesions: why Sampson seems to be right. European Journal of Obstetrics and Gynecology and Reproductive Biology 138 127-134. (doi:10.1016/j.ejogrb.2008.01.014)

Buchholz M, Biebl A, Neesse A, Wagner M, Iwamura T, Leder G, Adler G \& Gress TM 2003 SERPINE2 (protease nexin I) promotes extracellular matrix production and local invasion of pancreatic tumors in vivo. Cancer Research 63 4945-4951.

Chalpe A, Law C, Dumdie J, Hansen K \& Eyster K 2015 TNF $\alpha$ and IL1 $\beta$ stimulate differential gene expression in endometrial stromal cells. Advances in Biological Chemistry 5 126-141. (doi:10.4236/ abc.2015.52010)

Dobin A, Davis CA, Schlesinger F, Drenkow J, Zaleski C, Jha S, Batut P, Chaisson M \& Gingeras TR 2013 STAR: ultrafast universal RNA-seq aligner. Bioinformatics 29 15-21. (doi:10.1093/bioinformatics/bts635)

Dunselman GA, Vermeulen N, Becker C, Calhaz-Jorge C, D'Hooghe T, De Bie B, Heikinheimo O, Horne AW, Kiesel L, Nap A et al. 2014 ESHRE guideline: management of women with endometriosis. Human Reproduction 29 400-412. (doi:10.1093/humrep/det457)

Eyster KM, Klinkova O, Kennedy V \& Hansen KA 2007 Whole genome deoxyribonucleic acid microarray analysis of gene expression in ectopic 
versus eutopic endometrium. Fertility and Sterility 88 1505-1533. (doi:10.1016/j.fertnstert.2007.01.056)

Ferreira VP, Pangburn MK \& Cortes C 2010 Complement control protein factor $\mathrm{H}$ : the good, the bad, and the inadequate. Molecular Immunology 47 2187-2197. (doi:10.1016/j.molimm.2010.05.007)

Filippi I, Carrarelli P, Luisi S, Batteux F, Chapron C, Naldini A \& Petraglia F 2016 Different expression of hypoxic and angiogenic factors in human endometriotic lesions. Reproductive Sciences 23 492-497. (doi:10.1177/1933719115607978)

Gilabert-Estelles J, Ramon LA, Espana F, Gilabert J, Vila V, Reganon E, Castello R, Chirivella M \& Estelles A 2007 Expression of angiogenic factors in endometriosis: relationship to fibrinolytic and metalloproteinase systems. Human Reproduction 22 2120-2127. (doi:10.1093/humrep/ dem149)

Hardcastle TJ 2016 Generalized empirical Bayesian methods for discovery of differential data in high-throughput biology. Bioinformatics 32 195-202. (doi:10.1093/bioinformatics/btv569)

Hever A, Roth RB, Hevezi P, Marin ME, Acosta JA, Acosta H, Rojas J, Herrera R, Grigoriadis D, White E et al. 2007 Human endometriosis is associated with plasma cells and overexpression of B lymphocyte stimulator. PNAS 104 12451-12456. (doi:10.1073/pnas.0703451104)

Kasvandik S, Samuel K, Peters M, Eimre M, Peet N, Roost AM, Padrik L, Paju K, Peil L \& Salumets A 2016 Deep quantitative proteomics reveals extensive metabolic reprogramming and cancer-like changes of ectopic endometriotic stromal cells. Journal of Proteome Research 15 572-584. (doi:10.1021/acs.jproteome.5b00965)

Khorram O, Taylor RN, Ryan IP, Schall TJ \& Landers DV 1993 Peritoneal fluid concentrations of the cytokine RANTES correlate with the severity of endometriosis. American Journal of Obstetrics and Gynecology 169 1545-1549. (doi:10.1016/0002-9378(93)90433-J)

Kobayashi H, Yamashita Y, Iwase A, Yoshikawa Y, Yasui H, Kawai Y, Uchida K, Uno N, Akatsuka S, Takahashi T et al. 2012 The ferroimmunomodulatory role of ectopic endometriotic stromal cells in ovarian endometriosis. Fertility and Sterility 98 415-422.e411-e412. (doi:10.1016/j.fertnstert.2012.04.047)

Krjutskov K, Katayama S, Saare M, Vera-Rodriguez M, Lubenets D, Samuel K, Laisk-Podar T, Teder H, Einarsdottir E, Salumets A et al. 2016 Singlecell transcriptome analysis of endometrial tissue. Human Reproduction 31 844-853. (doi:10.1093/humrep/dew008)

Liu H, Wang J, Wang H, Tang N, Li Y, Zhang Y \& Hao T 2016 The plasma and peritoneal fluid concentrations of matrix metalloproteinase- 9 are elevated in patients with endometriosis. Annals of Clinical Biochemistry 53 599-605. (doi:10.1177/0004563215626458)

Livak KJ \& Schmittgen TD 2001 Analysis of relative gene expression data using real-time quantitative PCR and the 2(-Delta Delta C(T)) Method. Methods 25 402-408. (doi:10.1006/meth.2001.1262)

Love MI, Huber W \& Anders S 2014 Moderated estimation of fold change and dispersion for RNA-seq data with DESeq2. Genome Biology 15550. (doi:10.1186/s13059-014-0550-8)

Malik AB \& Lo SK 1996 Vascular endothelial adhesion molecules and tissue inflammation. Pharmacological Reviews 48 213-229.

Martin M 2011 Cutadapt removes adapter sequences from high-throughput sequencing reads. EMBnet.journal 17 10-12. (doi:10.14806/ej.17.1.200)

Meola J, Rosa e Silva JC, Dentillo DB, da Silva WA Jr, Veiga-Castelli LC, Bernardes LA, Ferriani RA, de Paz CC, Giuliatti S \& Martelli L 2010 Differentially expressed genes in eutopic and ectopic endometrium of women with endometriosis. Fertility and Sterility 93 1750-1773. (doi:10.1016/j.fertnstert.2008.12.058)

Morgan J, Spendlove I \& Durrant LG 2002 The role of CD55 in protecting the tumour environment from complement attack. Tissue Antigens $\mathbf{6 0}$ 213-223. (doi:10.1034/j.1399-0039.2002.600303.x)
Nisolle M \& Donnez J 1997 Peritoneal endometriosis, ovarian endometriosis, and adenomyotic nodules of the rectovaginal septum are three different entities. Fertility and Sterility 68 585-596. (doi:10.1016/ S0015-0282(97)00191-X)

Pizzo A, Salmeri FM, Ardita FV, Sofo V, Tripepi M \& Marsico S 2002 Behaviour of cytokine levels in serum and peritoneal fluid of women with endometriosis. Gynecologic and Obstetric Investigation 54 82-87. (doi:10.1159/000067717)

Reimand J, Arak T, Adler P, Kolberg L, Reisberg S, Peterson H \& Vilo J 2016 g:Profiler-a web server for functional interpretation of gene lists (2016 update). Nucleic Acids Research 44 W83-W89. (doi:10.1093/nar/ gkw199)

Robinson MD, McCarthy DJ \& Smyth GK 2010 edgeR: a bioconductor package for differential expression analysis of digital gene expression data. Bioinformatics 26 139-140. (doi:10.1093/bioinformatics/btp616)

Sanchez AM, Vigano P, Somigliana E, Panina-Bordignon P, Vercellini P \& Candiani M 2014 The distinguishing cellular and molecular features of the endometriotic ovarian cyst: from pathophysiology to the potential endometrioma-mediated damage to the ovary. Human Reproduction Update 20 217-230. (doi:10.1093/humupd/dmt053)

Sanchez AM, Vigano P, Somigliana E, Cioffi R, Panina-Bordignon P \& Candiani M 2015 The endometriotic tissue lining the internal surface of endometrioma: hormonal, genetic, epigenetic status, and gene expression profile. Reproductive Sciences 22 391-401. (doi:10.1177/1933719114529374)

Sohler F, Sommer A, Wachter DL, Agaimy A, Fischer OM, Renner SP, Burghaus S, Fasching PA, Beckmann MW, Fuhrmann U et al. 2013 Tissue remodeling and nonendometrium-like menstrual cycling are hallmarks of peritoneal endometriosis lesions. Reproductive Sciences 20 85-102. (doi:10.1177/1933719112451147)

Suryawanshi S, Huang X, Elishaev E, Budiu RA, Zhang L, Kim S, Donnellan N, Mantia-Smaldone G, Ma T, Tseng G et al. 2014 Complement pathway is frequently altered in endometriosis and endometriosisassociated ovarian cancer. Clinical Cancer Research 20 6163-6174. (doi:10.1158/1078-0432.CCR-14-1338)

Taketani Y, Kuo TM \& Mizuno M 1992 Comparison of cytokine levels and embryo toxicity in peritoneal fluid in infertile women with untreated or treated endometriosis. American Journal of Obstetrics and Gynecology 167 265-270. (doi:10.1016/S0002-9378(11)91672-X)

Tao XJ, Sayegh RA \& Isaacson KB 1997 Increased expression of complement component 3 in human ectopic endometrium compared with the matched eutopic endometrium. Fertility and Sterility $\mathbf{6 8}$ 460-467. (doi:10.1016/S0015-0282(97)00254-9)

Toomey CB, Cauvi DM \& Pollard KM 2014 The role of decay accelerating factor in environmentally induced and idiopathic systemic autoimmune disease. Autoimmune Diseases 2014452853. (doi:10.1155/2014/452853)

Witz CA 2003 Cell adhesion molecules and endometriosis. Seminars in Reproductive Medicine 21 173-182. (doi:10.1055/s-2003-41324)

Wu Y, Kajdacsy-Balla A, Strawn E, Basir Z, Halverson G, Jailwala P, Wang Y, Wang X, Ghosh S \& Guo SW 2006 Transcriptional characterizations of differences between eutopic and ectopic endometrium. Endocrinology 147 232-246. (doi:10.1210/en.2005-0426)

Received 15 February 2017

First decision 27 March 2017

Revised manuscript received 7 April 2017

Accepted 11 May 2017 